\title{
Bone Healing in Transverse Maxillary Defects with Different Surgical Procedures Using Anorganic Bovine Bone in Humans
}

\author{
Recuperación Ósea en Defectos Maxilares Transversales con Distintos \\ Procedimientos Quirúrgicos Utilizando Hueso Bovino Inorgánico en Humanos
}

\author{
Victor Beltrán"; Andries Matthijs"*; Eduardo Borie*; Ramón Fuentes*;'Iván Valdivia-Gandur ${ }^{* * * *}$ \& Wilfried Engelke***
}

BELTRÁN, V.; MATTHIJS, A.; BORIE, E.; FUENTES, R.; VALDIVIA-GANDUR, I. \& ENGELKE, W. Bone healing in transverse maxillary defects with different therapies with anorganic bovine bone in humans. Int. J. Morphol., 31(1):75-81, 2013.

SUMMARY: The centripetal resorption of maxilla is a continuous process after tooth loss. For treatment of deficient bone sites, autologous bone grafts may be used, as an alternative, biomaterials can be applied which do not require intra- or extraoral donor sites. The present report we describe the use of anorganic bovine bone (ABB) based on three case reports under different modes: Membrane, rigid barrier and connective tissue graft. Clinical results show that under all conditions, sufficient hard tissue was formed to allow implant born rehabilitation in the former insufficient bone sites. Histologic evaluation revealed trabecular bone in an almost mature matrix with resting particles of ABB. Depending on the original site situation, two step rigid occlusive barrier concept may be applied, if resting bone does not provide implant stability, whereas membrane covered augmentation in combination with connective tissue is recommended if simultaneous implant insertion is possible

KEY WORDS: Bone regeneration; Maxilla; Dental implant; Bone defect; Biomaterials.

\section{INTRODUCTION}

One of the main challenges currently in the implantology, is the development of even more predictable procedures, regardless the complexity of the clinical case. In this sense, one of the most important problems following tooth loss is the resorption process that suffers both jaws through time (Percac \& Nikolic, 1991). To recover the bone tissue some complex surgical procedures are required. One of these is the placement of bone autograft blocks, which are obtained from donor areas of the same patient from intraoral sites or from remote zones as the chin, calvaria and even hip or tibia. Moreover, as alternative to this surgical technique a combination of autograft and commercially available biomaterials may be used. The development of minimally invasive techniques for bone regeneration mainly implies the use of biomaterials (bone allografts), which has been advocated increasingly in the last years (Choi \& Engelke, 2009) exhibiting similar results to autologous bone.

Augmentation procedures required a complex planning, a high cost and sometimes a multistep long lasting therapy. Extended treatment periods may be necessary to reach the final aesthetic outcome, depending on the technique and the type of graft used for maxillary or mandibular bone healing.

Among the different biomaterials for bone regeneration on the market, the anorganic bovine bone $(\mathrm{ABB})$ presents an osteoconductive property with a replacement time between 6 and 8 months. It is available in unlimited quantities as a granular or block preparation. It`s main indication are periodontal defect filling and and maxillary sinus floor augmentations procedures in association with the use of membranes. Three phases have been described for bone regeneration with ABB: In the first stage the biomaterial particles are integrated in the surrounding bone tissue, in a second step resorption of these particles occurs by osteoclastic activity and finally, new bone formation is observed, when the particles are substituted by dense lamellar bone through osteoblastic activity (Figueiredo et al., 2009).

* Departamento Integral del Adulto, Facultad de Odontología, Universidad de La Frontera, Temuco, Chile.

** Department of Implantology and Periodontology, University of Nijmegen, Netherlands.

**** Departamento Biomédico, Facultad de Ciencias de la Salud, Universidad de Antofagasta, Antofagasta, Chile.

**** Dentistry Centre, Department of Maxillofacial Surgery, University of Göttingen, Göttingen, Germany. 
In the present report, we shall describe the application of $\mathrm{ABB}$ under three different conditions in order to give a survey of clinical options depending on different degrees of transversal maxillary bone resorption

\section{CASE REPORTS}

Patients were treated at the Dentistry Faculty of the Universidad de La Frontera, Temuco-Chile and at the Department of Periodontology and Implantology of Nijmegen University, Netherlands.

Three subjects without systemic disease, aged between 29 and 63 years presenting transverse maxillary bone defects with different levels of complexity were selected for treatment. Prior to surgery, the patients were informed about bone grafting procedures and the use of allograft, indicating the features and origin of the bone biomaterial that would be used after which the signed an informed consent. All cases were treated with particulate anorganic bovine bone (ABB) (Bio-Oss ${ }^{\circledR}$, Geistlich, Switzerland). The treatment realized were the following:

- ABB in conjunction with subepithelial connective tissue graft of palate,

- ABB in conjunction with a Rigid occlusive barrier (ROB) and

- $\mathrm{ABB}$ in conjunction with a collagen membrane.
Case 1. A 52 year-old female patient, without relevant background in medical history, was derived for rehabilitation by dental implants in a transverse maxillary bone defect located in the zone of teeth 2.1 and 2.2. due to a dental trauma suffered approximately 10 years ago. 3D images revealed a bone dimension of $3.9 \mathrm{~mm}$ in bucco-palatal direction and $13 \mathrm{~mm}$ in height. In this case a bone augmentation with particulate ABB in conjunction with a subepithelial connective tissue graft of patient's palate was planned. Once a mucoperiosteal flap was lifted (Fig. 1A), perforations were realized in the receptor bone to enhance the graft nutrition from medullary vessels. After ABB placement $(1 \mathrm{cc})$, a subepithelial connective graft was taken of the right side of palatal zone, placing it over the bone graft (Fig. 1B). Subsequently, the suture was performed with Vycril 4.0. After 6 months when a complete recovery was observed, two non-conical self-tapping implants (Replace Select Tapered, Nobel Biocare ${ }^{\circledR}$ ) were inserted, during this 6 months patient had a resin modified etchbridge without applying pressure during the first 3 months on the soft tissue after that period the bridge was 3 times modified with composite to create an ideal pontic bed.during second stage surgery 2 acrylic screwable transitional crowns were made chairside over titanium standard abutments these were modified 3 times during 3 months to create an ideal emergence profile, after the impression was taken using 2 individualized chairside made impression copings (open tray technique ) individualized zirconium oxide abutments were made with partial E-max (lithium disilicate) cemented crowns (Fig. 1C and D).

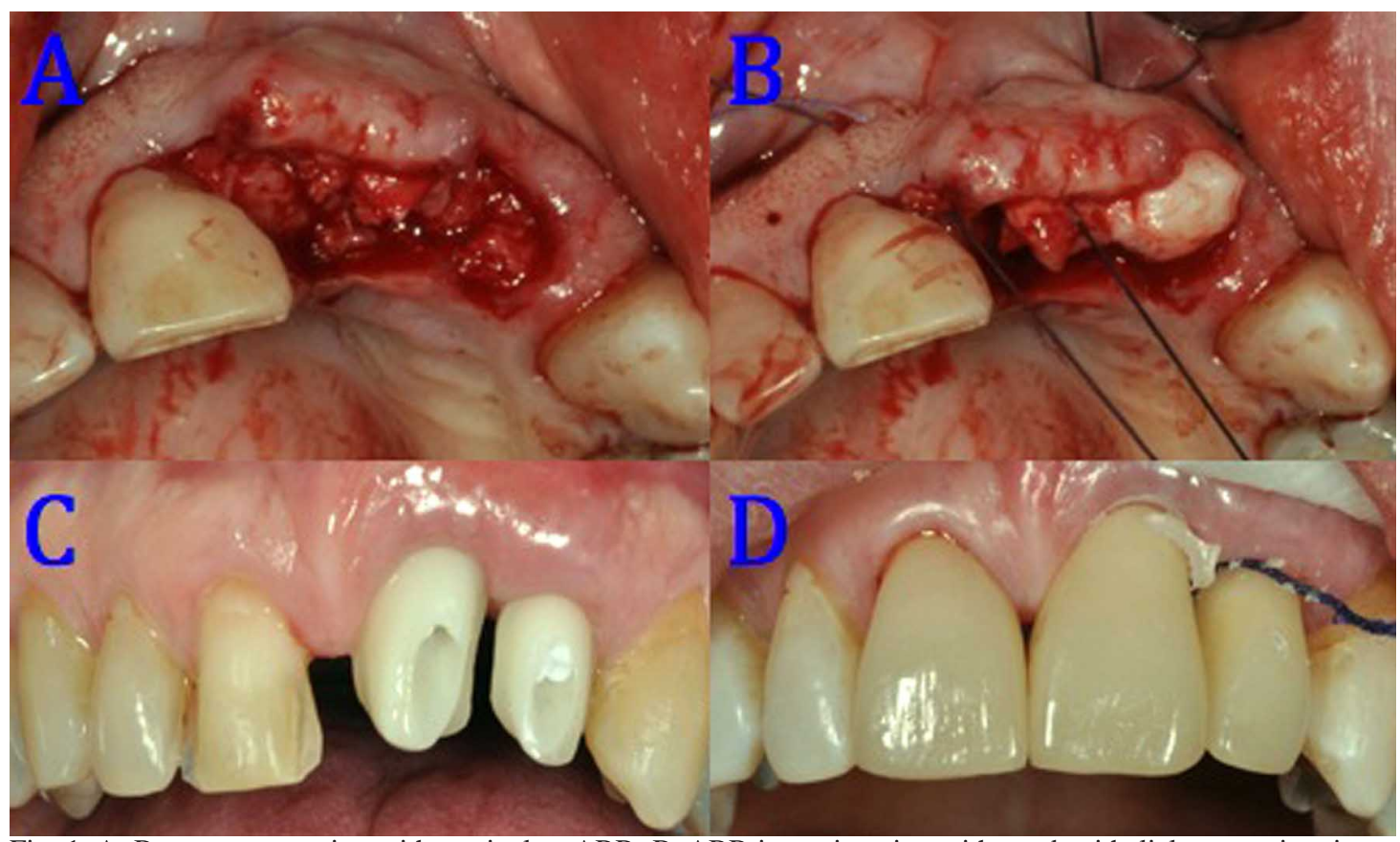

Fig. 1. A. Bone augmentation with particulate ABB; B. ABB in conjunction with a subepithelial connective tissue graft of patient's palate; C. After 6 months, the teeth were rehabilitated with two zirconia abutments; D. Final result. 
Case 2. A 29 year-old woman, without systemic disease, had lost a first maxillary premolar by a vertical root fracture after an endodontic treatment. Using a cone beam computerized tomography, a bucco-lingual bone thickness less than $3.5 \mathrm{~mm}$ was detected. The vertical dimension towards the sinus floor was $14 \mathrm{~mm}$. The

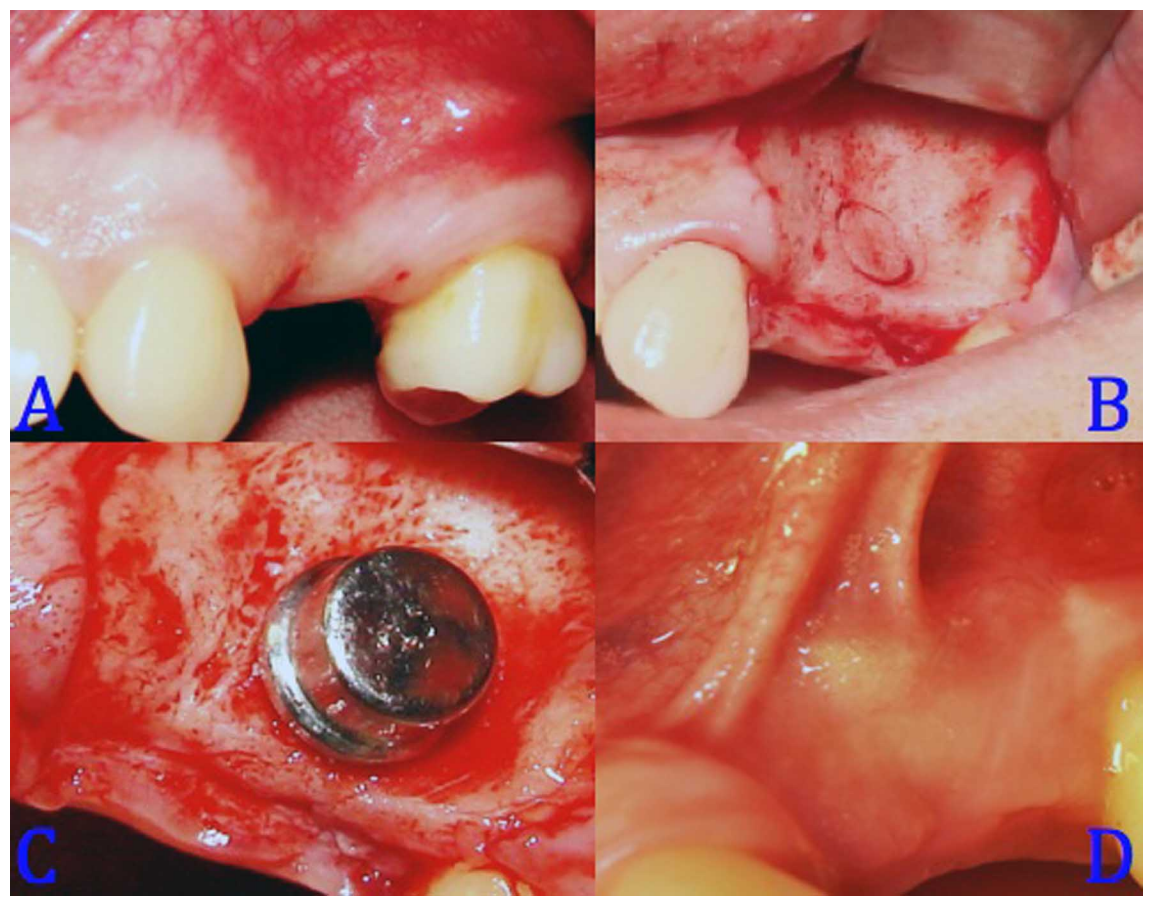

Fig. 2. A. Initial bone collapse; B. Creation of capsule support; C. Capsule placement; D. Capsule under the tissue after healing.

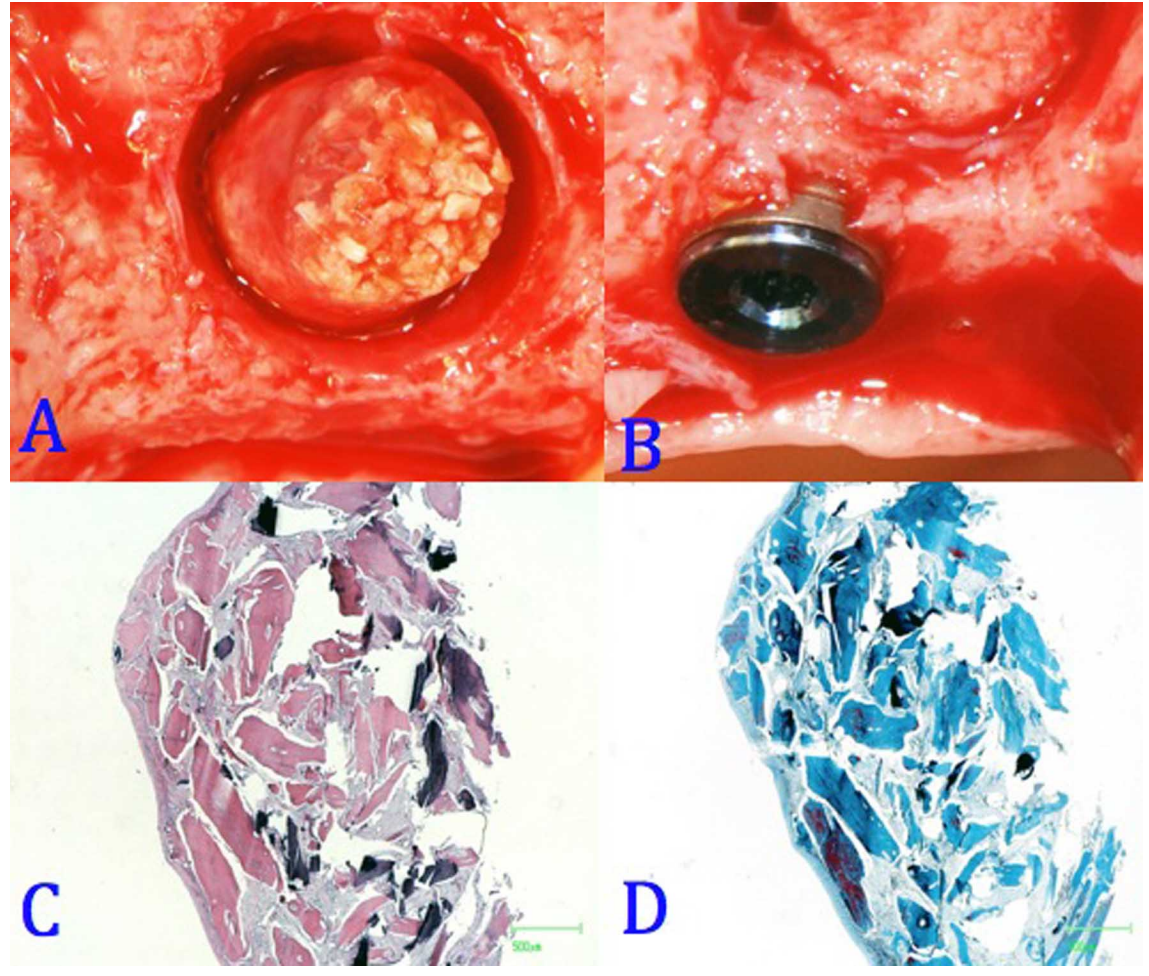

Fig. 3. A. Bone callus formed in the dome; B. Self-tapered implant placement; C and D. Bone trabeculae in an almost mature matrix with some areas in a lamellar organization. treatment consisted in the insertion of a rigid occlusive barrier (ROB) using a dome-shaped capsule (3.8 $\mathrm{mm}$ in height) with particulate $\mathrm{ABB}$ granules inside, under a mucoperiosteal flap, $3 \mathrm{~mm}$ at $3 \mathrm{~mm}$ distance from the sinus floor following the method of rigid barriers described by (Engelke et al., 2004). The device stability was achieved by pressure in a $2 \mathrm{~mm}$ intraosseous groove, created and adapted to capsule width (4 mm). Using rigid capsule, the material was stabilized mechanically and occluded towards the soft tissue (Fig. 2 A-D).

After 7 months, the ROB was extracted, a bone callus had formed in the dome (Fig. 3A), which led to an increase of the total width of the bone region intervened. The augmented area was provided with a self-tapered implant (Fig. 3B) (Alphabio, SPI ®) achieving an optimal initial stability of the implant (over $35 \mathrm{~N}$ ). Additional ABB was used to cover the groove where the capsule was placed. The implant was left submerged for three months, loading and prosthetic treatment was uneventful. The bone tissue found in the deeper zone of the capsule was analyzed by conventional histology (Fig. 3C and D). Bone trabeculae in an almost mature matrix were observed, with some areas in a lamellar organization. The trabeculae of medium and large size had abundant vascularization indicating that vital bone tissue was present with ongoing remodeling. The connective tissue between the trabeculae had no characteristics of medullary tissue because it's lacking of typical fat tissue, being more compatible with lax connective tissue with some areas of leuokocyte infiltration. Generally, the tissue organization was compatible with a fracture bone callus in remodeling in conjunction with $\mathrm{ABB}$ particles in remodellation. 
Case 3. A 63 year-old man, without systemic disease, reported the central upper left incisor loss by severe periodontal disease. After periodontal treatment and in the maintenance therapy, was placed an implant associated with a transverse localized maxillary defect. In this case the residual bone was approximately 4.5 $\mathrm{mm}$ in width and $13 \mathrm{~mm}$ in height. A cylindrical non self-tapered implant was placed. Augmentation was performed with a mixture of ABB biomaterial and the patient's blood simultaneously with the implant placement (Fig. 4A, B). The implant showed good primary stability, the site was covered with a resorbable collagen membrane (Bio-Guide ${ }^{\circledR}$ ) (Fig. 4 C- E). After six months a provisory crown was placed (Fig. 4F).

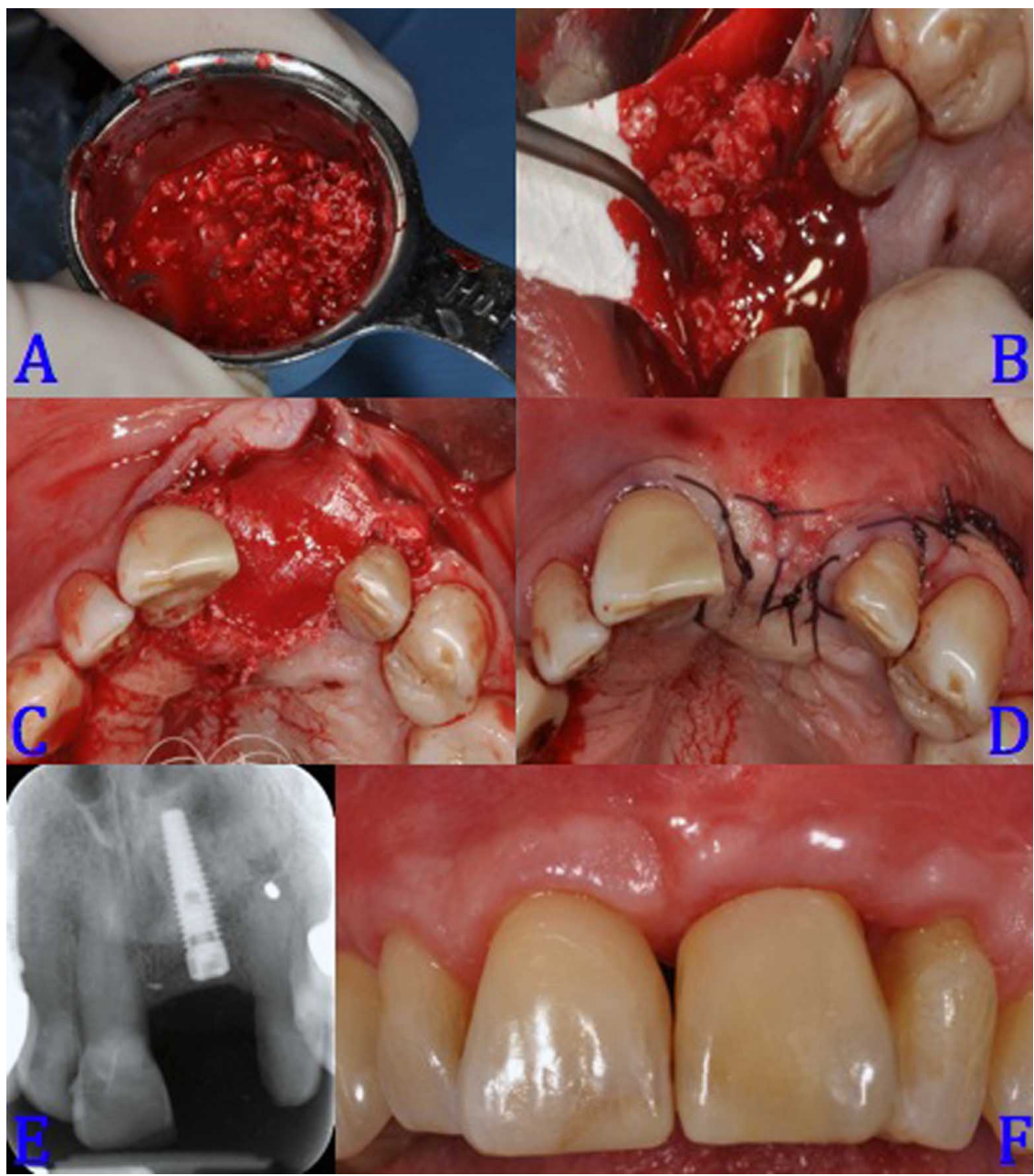

Fig. 4. A. Mixture of ABB biomaterial and the patient`s blood; B. Placement of bone graft; C. Cover with collagen membrane; D. Suture; E. Implant placement; F. Provisory crown.

\section{DISCUSSION}

One of the major disadvantages in the use of autologous bone graft is the extraction procedure of the same in an intraoral or extraoral donor site, observing frequently significant post-surgery sequelae (Infante-Cossío et al., 2007). Regarding to above, Nóia et al. (2012) evaluated the bone repair process of the mandibular symphysis using radiographs in the preoperative stage, immediate postoperative and late postoperative, in patients which were taken bone grafts from the chin for use as autografts in alveolar bone augmentation for implants treatment. The results of this study concluded that bone healing in the defect in a $30-50 \%$ of the cases takes place one year after the surgery. But has the following risks: paresthesia, scar formation, damage of adjacent teeth, postoperative morbidits.

Presently, an alternative treatment using allografts with minimally invasive surgical techniques have been shown to respond adequately to the needs of bone tissue recovery (Choi \& Engelke). These biomaterials are composed of anorganic elements or bone material, containing collagen matrix. They can also be used in combination with autografts or with some stimulators as the protein derived from porcine enamel (Martinez et al., 2011) other the platelet-rich plasma.

The association between surgical technique and bone grafts for alveolar bone defects healing, shows mixed results in systematic reviews of scientific evidence. Thus, Aghaloo \& Moy (2007) analyzed published results regarding different surgical techniques with and without association of alloplastic grafts, for bone crest recover purposes, not observing significant differences considering the percentage of implant survival.

Jensen et al. (2009), indicate that there is still evidence in the literature that high success rate is similar in implants placed in local bone as for the different techniques for bone augmentation. Chiapasco et al. 
(2009) in a review of the literature did not find clear evidence which surgical technique were most recommendable ridge augmentation procedures.

Moreover, the difference in the design of the implants does not appear to improve the survival of the implant (Hallman et al., 2005; Marchetti et al., 2008). Obviously, every procedure has advantages and disadvantages, but this lack of evidence does not confirm which procedure is best or most appropriate, those treatments should be preferred that are more conservative in all aspects, saving time and avoiding the unnecessary waste of biomaterials.

In the first case, combination of $\mathrm{ABB}$ and subepithelial tissue was used. The combination of $\mathrm{ABB}$ and subepithelial tissue allows a good coverage of the defect with bone tissue and a thick layer of keratinized tissue. Grafts with autologous keratinized tissue obtained from the palate have been used for both horizontal and vertical increase of the alveolar crest (Peñarrocha et al., 2005). However, the development of this technique requires more time and a donor site of keratinized tissue from the palate, so that from the surgical perspective is less conservative.

In the second case, a rigid occlusive barrier (ROB) was used, made by a non-osteoinductor and nonosteoconductor material, which was combined with $\mathrm{ABB}$ and fixed to the bone, with the aim of bone augmentation in horizontal way. Van Steenberghe et al., (2003) had previously designed a similar device to be screwed in mandibular defects in humans and rabbits, being three times larger than those used in the case described here. The researchers conclude that these procedures show comparable results with the use of autologous bone blocks in large mandibular bone defects. Engelke et al., designed totally occlusive screwed devices of smaller size, related with synthetic hydroxyapatite in maxillary and mandibular defects with less of $8 \mathrm{~mm}$ of width and height, showing favorable results.

The experience of these authors indicate that the use of bone grafts within a ROB placed over transverse bone defects, would allow a more predictable bone augmentation, fast and with better quality compared with unfilled bone barriers (Engelke et al.). The purpose of the barrier was to prevent the exposure of the healing zone during the first seven months, giving an absolute primary stabilization of the augmentation material. Capsule stiffness prevented the material from soft tissue pressure which might have flattened its shape. The patient did not present problems with ROB exposure or postsurgical infection. The most interesting finding of this technique was the bone tissue formation adapted to internal walls of the device. Histological analysis of the tissue found within the dome showed an organization compatible with trabecular bone tissue, with features of mature bone tissue, which was evident by the presence of lamellar organization areas similar to osteons. Consequently, this procedure is a highly viable alternative that ensures the maintenance of bone regeneration zone and adaptation of soft tissue around it.

In the third case presented in this report, the therapy used was ABB associated with blood and the use of a collagen membrane (Bio-Gide ()) to cover the biomaterial. This membrane is composed by porcine collagen fibers type I and III, and poorly immunogenic capacity without organic components or chemicals. It has a double layer structure, which protects the connective tissue infiltration and promotes the invasion of osteogenic cells. Some authors as Milagres et al., (2009) reported that mesenchymal cells from bone marrow may colonize the collagen membrane even faster than a bone graft. The use of collagen membranes is a more conservative technique compared with the use of a subepithelial graft obtained from a remote intraoral site. Following El Chaar (2010), the combination of collagen membranes with bone grafts and may be successfully applied in transverse maxillary bone defects. However, is susceptible to graft mobility or infection the first weeks, factors that are need to be considered to have influence on the clinical result.

First, the biomaterial selection to bone healing procedures in bone defects is based in their osteoconductive properties associated or not to osteoindutive factors, however is important to consider too the clinical case. According to Nascimento et al. (2007), the type and amount of tissue that is intended to regenerate must be considered, the stability and geometric conformation of the zone, the adjacent tissue vascularization and the possible inflammatory response. The above, may be associated with foreign bodies and the ability of the biomaterial to be biodegraded and replaced by new bone tissue. The ABB is a biomaterial formed by a porous, non-antigenic and mineralized bone matrix, which is widely used to repair bone defects. In a recent study by Jensen et al. (2012), they performed bilateral sinus floor lifts in 40 mini-pigs using particulate autogenous bone and Bio-Oss (ABB), concluding that the graft volume is better maintained when Bio-oss was added to autograft. Also, Schmitt et al. (2012) performed sinus lift in 30 posterior maxillary edentulous patients using bone graft as calcium bisphosphate (BCP, Straumann Bone Ceramic), anorganic bovine bone (ABB, Geistlich Bio-Oss), mineralized cancellous bone allograft (MCBA, Zimmer Puros) or autologous bone, finding no significant differences in the results observed. 
Moreover, the shape and size of the biomaterial particles can influence the behavior of the allograft used. Thus, Figueiredo et al., compared different granular bone biomaterials, some of theirs bovine (BioOss, PepGen P-15), of pigs (OsteoBiol), and of coral (Biocoral), being the bovine and porcine based on hydroxyapatite and the coralline based on calcium carbonate. The researchers found that even for those biomaterials with similar chemical features, significant differences were observed considering factors such as particle size, crystallinity, porosity, pore size distribution, surface area and mineral content. Also, it was suggested that these morphological characteristics should be considered when evaluating the performance of a bone graft, explaining the diversity of results found in the literature. Recently, Zhang et al., (2012) have used cancellous bone from deer antler ("Cervus Nippon" (CACB)) in the bone healing of mandibular defects in rabbits, finding similar results to BioOss as neovascularization induction and osteogenesis in bone defects.

Apparently, neither the surgical procedure nor the biomaterial used appears to have significant differences that can be related objectively to choose the best treatment for defect bone healing. However, it is important to point out that sometimes the success of failure of a specific treatment has a direct relation with patient factors.
Finally, the surgical techniques discussed in this cases presentation are different in complexity but the literature shows no evidence to indicate significant differences in favor or against the therapeutic results obtained with each of them. Given this lack of information, the procedures that had conservative surgical protocols and which are less sensitive to operator factor, should be preferred for patients that require the intervention. conclude:

Regarding the value of different procedures we - The use of a connective tissue graft is valuable in case o missing gingival attachment and can be successfully combined with transverse particulate augmentation in a 2 stage procedure.

- The use of ROB always needs secondary surgery, when a transverse gain of bone volume is intended with standardized ROB`s. It could be demonstrated, that the formation of mature bone can be achieved in a moderately clinical case, nevertheless for simple augmentations, a one-stage procedure without ROB may be preferred.

- The combination of collagen membranes and ABB appears to be an adequate procedure in case of low-grade atrophy with sufficient local bone to provide implants primary stability in a one-stage surgery.

BELTRÁN, V.; MATTHIJS, A.; BORIE, E.; FUENTES, R.; VALDIVIA-GANDUR, I. \& ENGELKE, W. Recuperación ósea en defectos maxilares transversales con distintos procedimientos quirúrgicos utilizando hueso bovino inorgánico en humanos. Int. J. Morphol., 31(1):75-81, 2013.

RESUMEN: La reabsorción centrípeta del maxilar es un proceso continuo después de la pérdida dentaria. Para el tratamiento de sitios óseos deficientes, se pueden utilizar injertos de hueso autólogo; como alternativa, se puede aplicar biomateriales, que no requieren sitios donantes intra o extraorales. Se describe el uso de hueso inorgánico bovino (HIB) base en tres casos en diferentes modos: membrana, barrera rígida e injerto de tejido conectivo. Los resultados clínicos muestran que en todas las condiciones se formó suficiente tejido duro para permitir la rehabilitación de implantes en los sitios de hueso insuficiente. La evaluación histológica reveló hueso trabecular en una matriz casi madura con partículas en reposo de HIB. Dependiendo de la situación del sitio original, se puede aplicar el concepto de barrera oclusiva rígida en dos pasos, si el hueso en reposo no proporciona la estabilidad del implante, mientras que el aumento cubierto con membrana en combinación con tejido conectivo se recomienda si es posible la inserción simultánea de implantes.

PALABRAS CLAVE: Regeneración ósea; Maxilar; Implante dental; Defectos óseos; Biomateriales.

\section{REFERENCES}

Aghaloo, T. L. \& Moy, P. K. Which hard tissue augmentation techniques are the most successful in furnishing bony support for implant placement? Int. J. Oral Maxillofac. Implants, 22 Suppl:49-70, 2007.

Chiapasco, M.; Casentini, P. \& Zaniboni, M. Bone augmentation procedures in implant dentistry. Int. J. Oral Maxillofac. Implants, 24 Suppl:237-59, 2009.
Choi, B. H. \& Engelke, W. Flapless Implantology - Möglichkeiten und Grenzen. Implantologie, 17:139, 2009.

El Chaar, E. S. Soft tissue closure of grafted extraction sockets in the posterior maxilla: the rotated pedicle palatal connective tissue flap technique. Implant Dent., 19(5):370-7, 2010.

Engelke, W.; Decco, O. \& Rau, M. J. Minimal invasive 
Augmentation des Unterkiefers mit einem mikrofixierten starren Formkörper. Das deutsche Zahnärzteblatt, 113(9):399402, 2004.

Figueiredo, M.; Henriques, J.; Martins, G.; Guerra, F.; Judas, F. \& Figueiredo, H. Physicochemical characterization of biomaterials commonly used in dentistry as bone substitutes-comparison with human bone. J. Biomed. Mater. Res. B Appl. Biomater., 92(2):409-19, 2010.

Hallman, M.; Mordenfeld, A. \& Strandkvist, T. A retrospective 5year follow-up study of two different titanium implant surfaces used after interpositional bone grafting for reconstruction of the atrophic edentulous maxilla. Clin. Implant Dent. Relat. Res., 7(3):121-6, 2005.

Infante-Cossío, P.; Gutiérrez-Pérez, J. L.; Torres-Lagares, D.; García-Perla García, A. \& González-Padilla, J. D. Relleno de cavidades óseas en cirugía maxilofacial con materiales autólogos. Rev. Esp. Cirug. Oral y Maxilofac., 29(1):7-19, 2007.

Jensen, T.; Schou, S.; Svendsen, P. A.; Forman, J. L.; Gundersen, H. J.; Terheyden, H. \& Holmstrup, P. Volumetric changes of the graft after maxillary sinus floor augmentation with BioOss and autogenous bone in different ratios: a radiographic study in minipigs. Clin. Oral Implants Res., 23(8):902-10, 2012 .

Jensen, S. S. \& Terheyden, H. Bone augmentation procedures in localized defects in the alveolar ridge: clinical results with different bone grafts and bone-substitute materials. Int. J. Oral Maxillofac. Implants, 24 Suppl:218-36, 2009.

Marchetti, C.; Pieri, F.; Corinaldesi, G. \& Degidi, M. A long-term retrospective study of two different implant surfaces placed after reconstruction of the severely resorbed maxilla using Le Fort I osteotomy and interpositional bone grafting. Int. J. Oral Maxillofac. Implants, 23(5):911-8, 2008.

Martínez, G.; Llamosa, L.; Beltrán,V.; Cantín, M. \& Fuentes, R. Periodontal Therapy by Enamel Matrix-derived Protein and Bone Allograft. Int. J. Odontostomat., 5(3):279-86, 2011.

Milagres, D.; Rueff-Barroso, C. R.; Carvalho, S. N.; Carvalho, L.; Monte-Alto-Costa; Fischer, R. G. \& Porto, L. C. Early proliferation of bone marrow mononuclear cells on collagen membrane, bone graft and tooth cementum. Int. J. Morphol., 27(4):1249-56, 2009.

Nascimento, C.; Issa, J. P. M.; Oliveira, R. R.; Iyomasa, M. M.; Siéssere, S. \& Regalo, S. C. H. Biomaterialsapplied to the bone healing process. Int. J. Morphol., 25(4):839-46, 2007.

Nóia, C. F.; Ortega-Lopes, R.; Sato, F. R. L.; Olate, S. \& Mazzonetto, R. Estudio radiográfico prospectivo de la reparación ósea en sínfisis mandibular posterior a la remoción ósea de mentón. Int. J. Morphol., 30(1):100-4, 2012.
Peñarrocha, M.; García-Mira, B. \& Martinez, O. Localized vertical maxillary ridge preservation using bone cores and a rotated palatal flap. Int. J. Oral Maxillofac. Implants, 20(1):131-4, 2005 .

Percac, S. \& Nikolic, V. Influence of teeth loss on morphometric characteristics of the maxilla. Acta Stomatol. Croat., 25(4):199205, 1991.

Schmitt, C. M.; Doering, H.; Schmidt, T.; Lutz, R.; Neukam, F. W. \& Schlegel, K. A. Histological results after maxillary sinus augmentation with Straumann ${ }^{\circledR}$ BoneCeramic, Bio-Oss ${ }^{\circledR}$, Puros $\AA$, and autologous bone. A randomized controlled clinical trial. Clin. Oral Implants Res., doi: 10.1111/j.16000501.2012.02431.x., 2012.

Van Steenberghe, D.; Johansson, C.; Quirynen, M.; Molly, L.; Albrektsson, T. \& Naert, I. Bone augmentation by means of a stiff occlusive titanium barrier. Clin. Oral Implants Res., 14(1):63-71, 2003.

Zhang, X.; Cai, Q.; Liu, H.; Heng, B. C.; Peng, H.; Song, Y.; Yang, Z. \& Deng, X. Osteoconductive effectiveness of bone graft derived from antler cancellous bone: an experimental study in the rabbit mandible defect model. Int. J. Oral Maxillofac. Surg., 41(11):1330-7, 2012.

\section{Correspondence to:}

Víctor Javier Beltrán Varas

Faculty of Dentistry

Universidad de La Frontera

Claro Solar No 115 - Of. 420, Temuco

CHILE

Email: victor.beltran@ufrontera.cl

Received: 25-09-2012

Accepted: 03-01-2013 